\title{
T1 and T2 Mapping in Cardiology: "Mapping the Obscure Object of Desire"
}

\author{
Sophie Mavrogeni ${ }^{\mathrm{a}}$ Dimitris Apostolou $^{\mathrm{b}}$ Panayiotis Argyriou ${ }^{\mathrm{b}}$ \\ Stella Velitsista ${ }^{\mathrm{b}}$ Lilika Papa $^{\mathrm{b}}$ Stelios Efentakis ${ }^{\mathrm{b}}$ Evangelos Vernardos ${ }^{\mathrm{b}}$

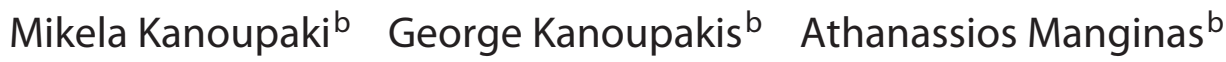 \\ ${ }^{\mathrm{a}}$ Onassis Cardiac Surgery Center, and ${ }^{\mathrm{b}}$ Mediterraneo Hospital, Athens, Greece
}

\section{Keywords}

Cardiovascular magnetic resonance $\cdot$ Heart diseases .

T1 mapping · T2 mapping

\section{Abstract}

The increasing use of cardiovascular magnetic resonance (CMR) is based on its capability to perform biventricular function assessment and tissue characterization without radiation and with high reproducibility. The use of late gadolinium enhancement (LGE) gave the potential of non-invasive biopsy for fibrosis quantification. However, LGE is unable to detect diffuse myocardial disease. Native T1 mapping and extracellular volume fraction (ECV) provide knowledge about pathologies affecting both the myocardium and interstitium that is otherwise difficult to identify. Changes of myocardial native $\mathrm{T} 1$ reflect cardiac diseases (acute coronary syndromes, infarction, myocarditis, and diffuse fibrosis, all with high T1) and systemic diseases such as cardiac amyloid (high T1), Anderson-Fabry disease (low T1), and siderosis (low T1). The ECV, an index generated by native and postcontrast T1 mapping, measures the cellular and extracellular interstitial matrix (ECM) compartments. This myocyte-ECM dichotomy has important implications for identifying specific therapeutic targets of great value for heart failure treatment. On the other hand, T2 mapping is superior compared
\end{abstract}

\section{KARGER}

(C) 2017 S. Karger AG, Basel

E-Mail karger@karger.com

www.karger.com/crd with myocardial T1 and ECM for assessing the activity of myocarditis in recent-onset heart failure. Although these indices can significantly affect the clinical decision making, multicentre studies and a community-wide approach (including MRI vendors, funding, software, contrast agent manufacturers, and clinicians) are still missing.

(c) 2017 S. Karger AG, Basel

\section{Introduction}

The increasing use of cardiovascular magnetic resonance $(\mathrm{CMR})$ in clinical practice is based on the accurate and highly reproducible measurements. CMR, through the assessment of late gadolinium enhancement (LGE), gave to cardiology the great opportunity of non-invasive biopsy for fibrosis quantification. Details provided by LGE give information about the underlying pathophysiology and are related to prognosis and response to treatment [1-5]. However, LGE requires regional relative differences in the signal intensity between normal and abnormal myocardium and is unable to detect diffuse myocardial disease [6]. Therefore, a more detailed tissue characterization remains the "obscure object of desire" in cardiology. 
Recent advances in CMR allow reliable tissue characterization, based on the absolute quantifiable differences in recovery rates of longitudinal magnetization by $\mathrm{T} 1$ mapping [7]. T1 mapping is a robust and highly reproducible index that provides meaningful measurements reflecting important myocardial properties [8]. The proposed T1-based indices include native $\mathrm{T} 1$, which reflects myocardial disease involving the myocyte and interstitium without the need for gadolinium, and T1 post-contrast that reflects diffuse myocardial fibrosis. Extracellular volume fraction (ECV) is a direct gadolinium-based measurement of the size of the extracellular space, reflecting only interstitial disease [9]. ECV attempts to dichotomize the myocardium into a cellular and an interstitial component, expressed as volume fractions. Current advances in $\mathrm{T} 1$ measurement allow the routine non-invasive measurement of ECV.

\section{Clinical Implications of New CMR Indices}

\section{Native (Non-Contrast) T1}

The native (non-contrast) T1 measurement of myocardium allows the non-invasive detection of biologically important phenomena and promises to improve our diagnostic capability, measures the disease severity, and potentially influences the prognosis. It can detect important pathophysiologic processes, related to excess of water as in oedema $[9,10]$, protein deposition $[11,12]$, and other T1-altering substances, such as lipid [13, 14] or iron (haemorrhage, siderosis) [15], without the use of gadolinium, and therefore it can also be applied in patients with severe renal failure.

Changes of myocardial native T1 mapping reflect cardiac diseases, such as acute coronary syndromes, infarction, myocarditis, and diffuse fibrosis (that are presented with high T1) [16], and systemic diseases, such as cardiac amyloid (high T1) [16] Anderson-Fabry disease (low T1) [17], and siderosis (low T1). By including native T1 mapping in a CMR scan, we can reveal various pathologies, such as area at risk in acute coronary syndromes $[9,10$, 18], global myocarditis without LGE and preclinical cardiac involvement, due to iron overload, Fabry disease, cardiac amyloid, etc. $[11,13,19]$.

Native T1 mapping can be influenced by various pathologic processes and therefore it should be interpreted cautiously with consideration of the clinical background. Ferreira et al. [10] reported that, in 21 patients with acute regional myocardial oedema and no infarction and 21 healthy patients, native T1 mapping with a thresh- old of $990 \mathrm{~ms}$ had a sensitivity and specificity of $92 \%$ compared with T2 ratio using STIRT2 and ACUT2E. However, the receiver operator characteristics analysis showed that T1 mapping had a significantly larger area under the curve (AUC $=0.94$ ) compared with T2-weighted (T2W) methods, whether the reference ROI was skeletal muscle or remote myocardium (AUC $=0.58-0.89$; $p<0.03$ ). Messroghli et al. [20] evaluated 24 patients with acute infarction and reported that native T1 mapping with a threshold of 1,120 ms or more (mean plus 3 standard deviations) had a sensitivity and specificity of 96 and $91 \%$, respectively, compared with LGE that served as the reference.

\section{Post-Contrast T1 Mapping and ECV}

After administration of a contrast agent, myocardiumcontaining fibrosis demonstrates prolonged washout of gadolinium, related to decreased density of capillaries within the scar tissue and an increased distribution of extracellular volume [21]. An increased concentration of gadolinium relaxes the adjacent protons much faster than usual, causing T1 shortening, expressed as an area of high signal intensity on LGE images [22]. The extent of collagen deposition within the myocardium varies depending on the type and severity of the cardiac disease. Focal scarring refers to an area of replacement fibrosis that is detected by LGE. However, diffuse, interstitial fibrosis at histopathologic analysis cannot be detected by LGE. The use of LGE to depict focal scarring depends on the visual differences in signal intensity between regions of scarring and adjacent normal myocardium. On standard LGE images, diffuse fibrosis lacks these differences in signal intensity and may not be visually distinguished from normal myocardium. In contrast, in diffuse, interstitial fibrosis, the application of inversion pulses with standard delayed contrast-enhanced CMR techniques uniformly suppresses the entire myocardium, despite the presence of retained gadolinium, due to fibrosis, and therefore LGE cannot be detected.

T1 mapping overcomes these limitations by measuring the intrinsic T1 time of the evaluated tissue. As expected, non-contrast $\mathrm{T} 1$ time in normal myocardium is longer compared with post-contrast $\mathrm{T} 1$ time. This is due to the small amount of residual gadolinium in the interstitium, which has a relaxing effect [23] and is amplified by the increased volume of retained gadolinium in patients with diffuse fibrosis and even more in patients with regional scarring. In controls, normal post-contrast myocardial T1 times are reported to be $340-579 \mathrm{~ms}$, while in patients with cardiac disease they are reported to be 250 
580 ms. Post-contrast T1 mapping with a threshold of 392 ms or less (mean plus 3 standard deviations) was reported to have a sensitivity and specificity of 100 and $95 \%$, respectively, in patients with chronic myocardial infarction [20]. The ECV in the myocardium may be estimated from the concentration of extracellular contrast agent in the myocardium relative to the blood in a dynamic steady state. The change in relaxation rate $\Delta \mathrm{R} 1$ (where $\mathrm{R} 1=1$ / $\mathrm{T} 1)$ between pre- and post-contrast is directly proportional to the Gd-DTPA concentration: $\Delta \mathrm{R} 1=\gamma$ [GdDTPA] $\left(\gamma=4.5 \mathrm{~L} \mathrm{mmol}^{-1} \mathrm{~s}^{-1}\right)$. A dynamic steady state exists for tissues that have a contrast exchange rate with the blood which is faster than the net clearance of contrast from the blood. A dynamic steady state between the plasma and interstitium may be achieved by slow intravenous infusion, or by imaging $15 \mathrm{~min}$ following an intravenous bolus administration for normally perfused myocardium, while $15 \mathrm{~min}$ may not be adequate for recently infarcted myocardium [24].

$$
\mathrm{ECV}=(1-\text { hematocrit }) \frac{(1 / \mathrm{T} 1 \text { myopost }-\mathrm{T} 1 \text { myopre })}{(1 / \mathrm{T} 1 \text { bloodpost }-\mathrm{T} 1 \text { bloodpre })} \text {. }
$$

The ECV technique introduces an important new method sensitive to the distribution of the cellular (dominated by myocyte mass) and extracellular interstitial matrix (ECM) compartments. Alterations in these compartments occur during various pathophysiologic processes [10]. Early data proved that ECV measures are of prognostic value equal to left ventricular ejection fraction (LVEF) $[20,21]$. However, LVEF underscores the biologic importance of the interstitial matrix. This myocyteECM expansion dichotomy may have important implications for identifying distinct therapeutic targets, such as the fibroblasts versus the myocytes that are of great value for heart failure [22]. The extent to which primary ECM expansion from fibroblast activation drives myocyte dysfunction or the extent to which primary myocyte disease leads to ECM expansion in heart failure remains poorly understood, but at least now cardiology has a promising tool to quantify the expansion of interstitial matrix.

In the absence of amyloid or oedema, expansion of the myocardial collagen volume fraction is responsible for most ECM expansion [25] that leads to mechanical [2628], electrical [29-32], and vasomotor dysfunction [33]; these represent key parameters of cardiac vulnerability [34] and diminish tolerance to ischaemic insults [35-37]. Other studies introduced the idea of "vulnerable interstitium" in sudden cardiac death [37], and described bandlike fibrosis in the myocardium resembling hepatic cirrhosis [38]. Fibrosis is considered as a final common

T1 and T2 Mapping in Heart Disease

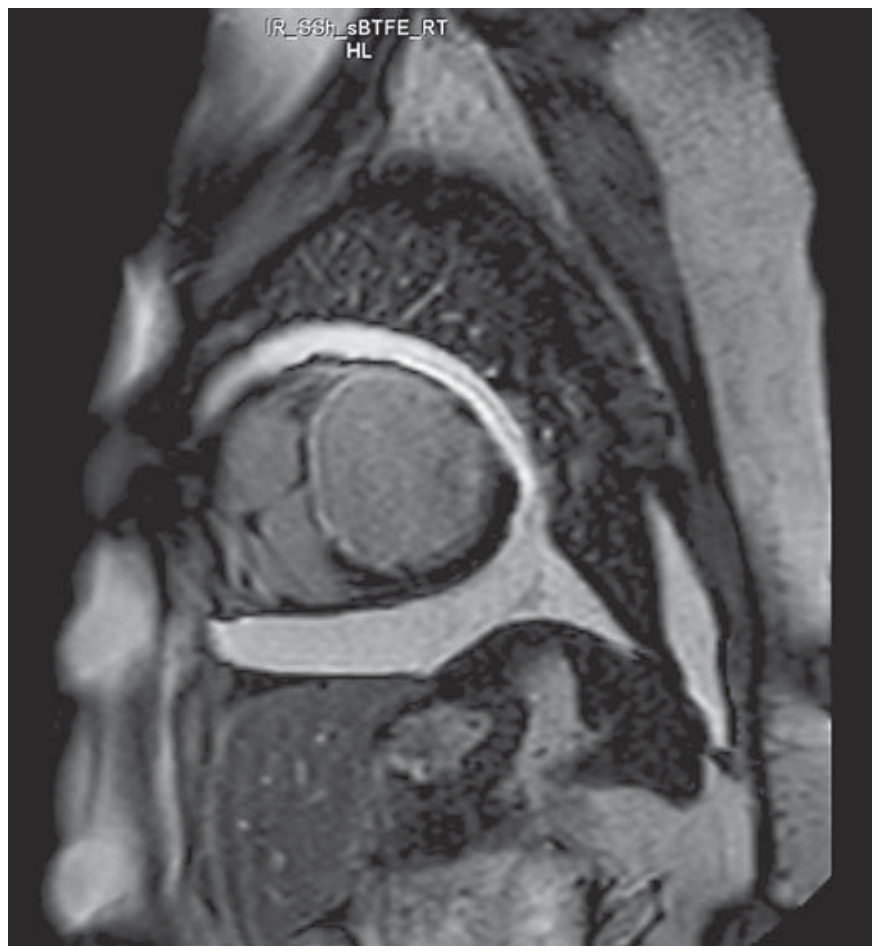

Fig. 1. Inversion recovery sequence showing extensive anteroseptal transmural myocardial infarction.

pathway of many myocardial diseases [39, 40]. Although LGE provides important diagnostic and prognostic information [41-47], T1 mapping and ECV may have an advantage over LGE for quantifying the degree of ECM or interstitial expansion. Furthermore, LGE is less suitable for quantifying the extent of ECM expansion [48-54], due to pathologic processes, where the differences between normal and affected myocardium are less distinct. ECV has better correlation with outcomes than LGE in non-ischaemic cardiomyopathy, due to either primary myocardial or systemic diseases, and may provide additive value beyond age, gender, renal function, myocardial infarction extent, ejection fraction, and heart failure stage [55-60]. Furthermore, ECV, a marker of interstitial fibrosis, and $\tau$ ic, a cell size-dependent parameter, can detect myocardial tissue remodelling from pressure overload [61].

This model has also been used to identify the attenuation of interstitial fibrosis and cardiomyocyte hypertrophy in hypertensive heart disease after treatment with spironolactone [62].

Currently, the application of these new indices opens new horizons in both the diagnosis and treatment of all

Cardiology 2017;138:207-217 DOI: $10.1159 / 000478901$ 


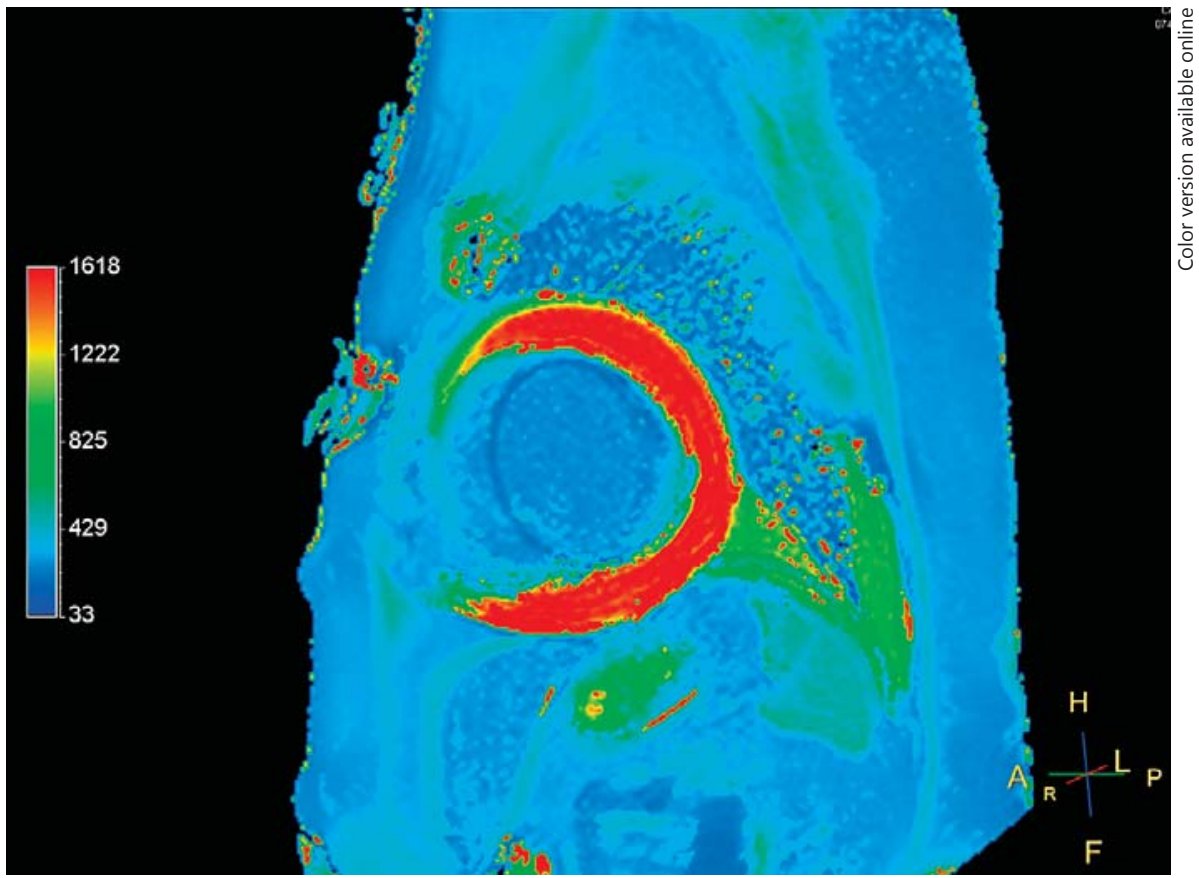

Fig. 2. Post-contrast T1 mapping from the same patient.

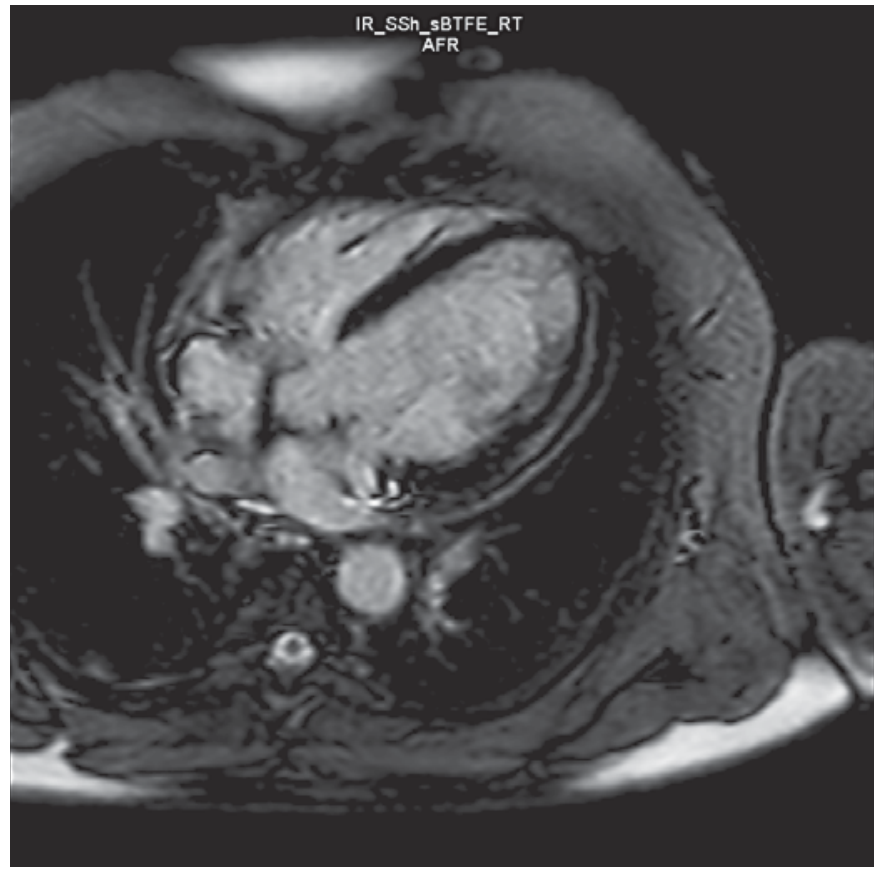

Fig. 3. Inversion recovery sequence showing extensive subepicardial fibrosis in the lateral wall of the left ventricle, due to myocarditis. patients in whom oedema and microfibrosis assessment is needed, including aortic stenosis, hypertrophic cardiomyopathy (HCM), myocarditis, ischaemic and non-ischaemic cardiomyopathy, heart failure of any aetiology, and rheumatic, neuromuscular, and endocrine diseases with cardiac involvement (Fig. 1-6). Specifically, shortened post-contrast $\mathrm{T} 1$ times in non-ischaemic and ischaemic cardiomyopathy $[63,64]$ were detected, even after exclusion of LGE areas, consistent with autopsy studies [65, $66]$. Additionally, shortened post-contrast $\mathrm{T} 1$ times and increased ECV have also been documented in HCM [67, 68], mirroring the myocardial disarray and interstitial fibrosis observed at autopsy [69]. Studies evaluating the interaction between genotypic and phenotypic expression in HCM, with expansion of ECV reported in gene-positive but phenotype-negative HCM patients [68], supporting that subclinical myocardial alterations precede the progression of phenotypic HCM in gene-positive patients. Furthermore, comparison of patients with HCM based on the presence or absence of a known HCM gene revealed differences in the 2 groups regarding the extent of interstitial fibrosis [70], leading to a better understanding of the heterogeneous nature of this disease.

Finally, this new approach offers the great opportunity to reliably and reproducibly validate the effect on the myocardium of various medications including new drugs for heart failure, as well as rheumatic and oncologic medications. 


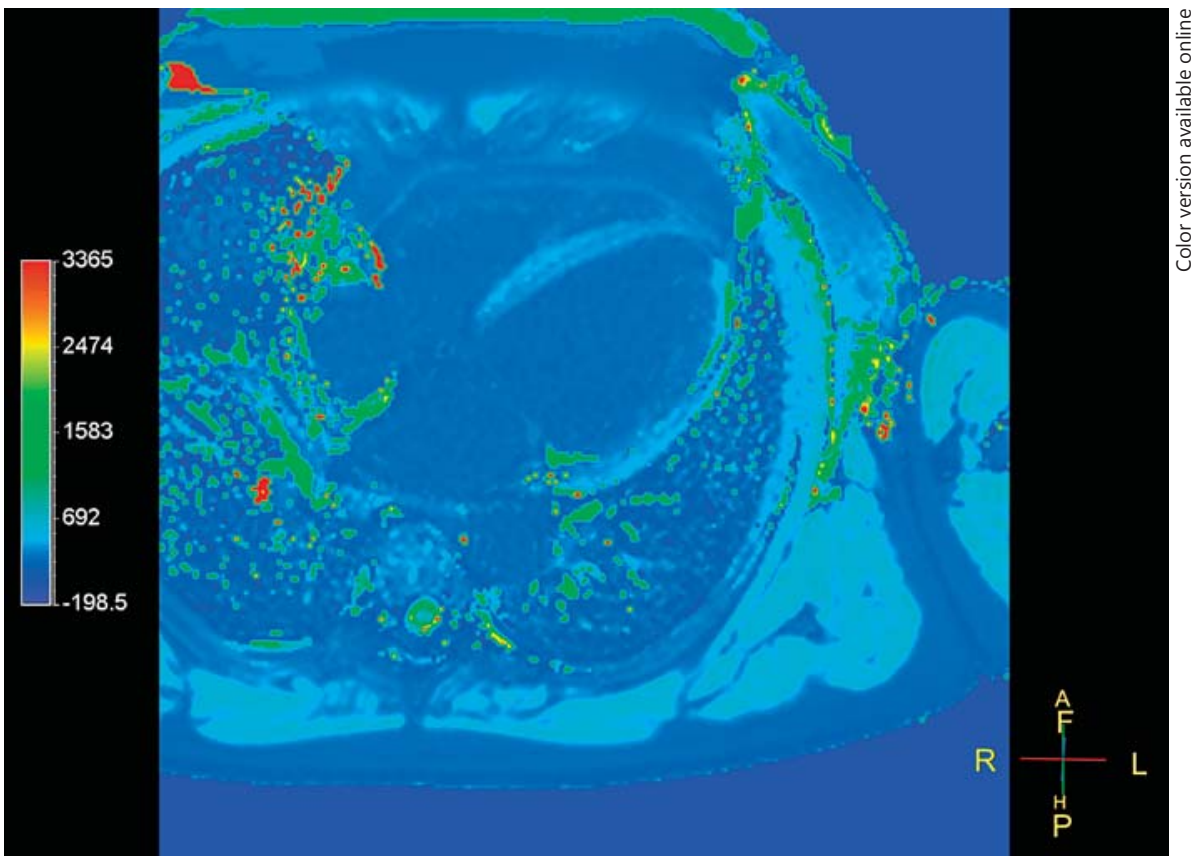

same patient.

\section{T2 Mapping}

T2W magnetic resonance imaging pulse sequences have been used to detect oedema in patients with acute myocardial infarction, differentiate acute from chronic infarction, and identify acute myocarditis. However, $\mathrm{T} 2 \mathrm{~W}$ sequences have suffered from various problems including (a) signal intensity variability caused by phased array coils, (b) high signal from slow-moving ventricular blood that can mimic and mask elevated T2 in subendocardium, (c) motion artefacts, and (d) the subjective nature of T2W image interpretation, unless it is expressed as T2 signal of myocardium versus T2 signal intensity of skeletal muscle (normal value $<1.9$ ).

The T2 mapping technique can accurately and reliably detect areas of myocardial oedema without the limitations of qualitative T2W imaging. T2 mapping sequences are useful for the detection of myocardial oedema due to acute myocardial infarction [71], myocarditis [72, 73], stress cardiomyopathy [72, 64], sarcoidosis [74], and cardiac allograft rejection [75]. Normal myocardial T2 values acquired using steady-state free precession MRI have been reported to be $52.18 \pm 3.4 \mathrm{~ms}$ at $1.5 \mathrm{~T}$ [76] and 45.1 $\mathrm{ms}$ at $3 \mathrm{~T}$ [77].

T2 mapping is considered superior compared with standard CMR parameters, global myocardial T1 mapping, and ECV for assessing the activity of myocarditis in patients with recent-onset heart failure and reduced left ventricular function (Fig. 6) [78]. Furthermore, T2 map-

T1 and T2 Mapping in Heart Disease

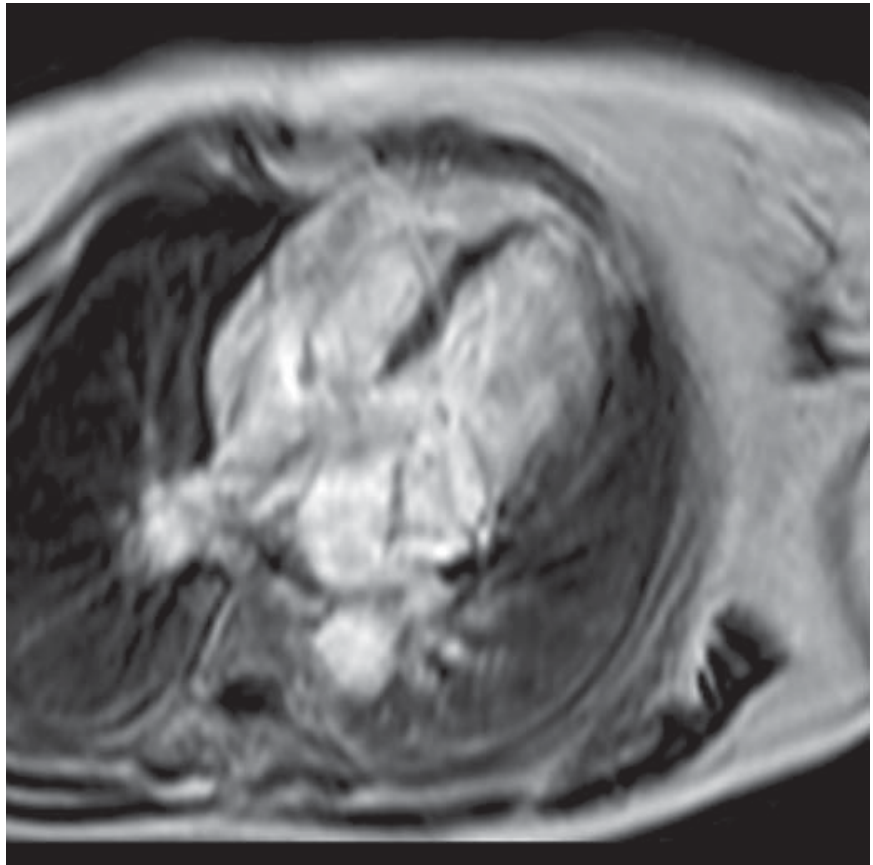

Fig. 5. Inversion recovery sequence showing extensive intramyocardial fibrosis in a patient with Sjogren syndrome.

Cardiology 2017;138:207-217 DOI: $10.1159 / 000478901$ 


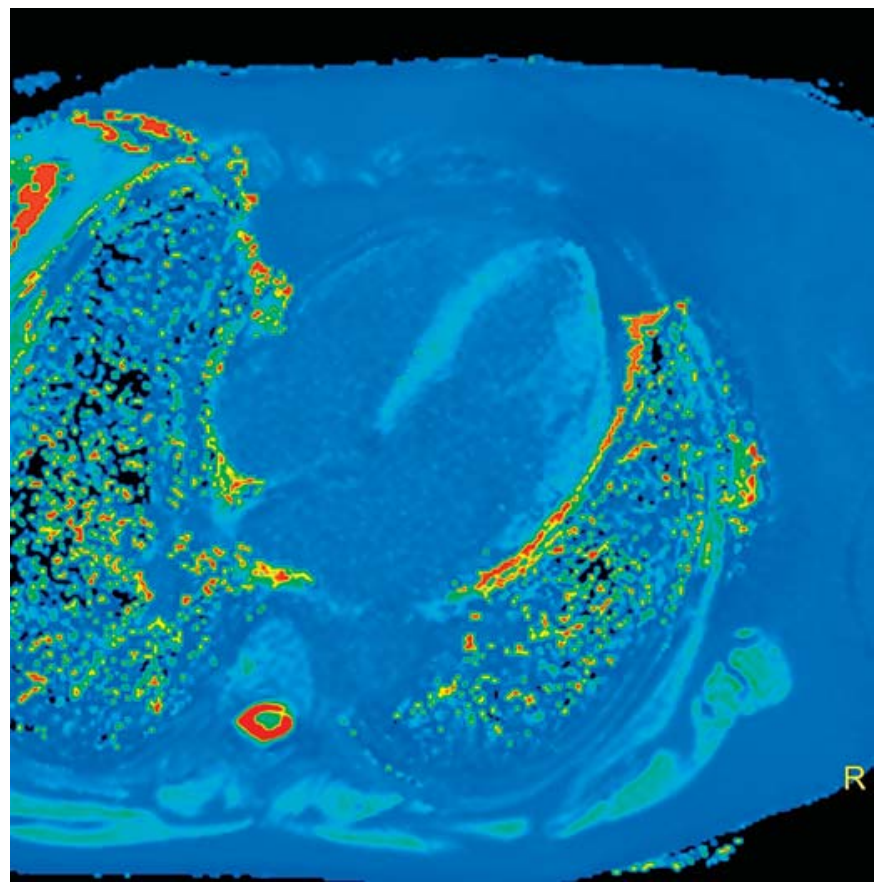

Fig. 6. Post-contrast T1 mapping from the same patient.

ping was proven to be a novel non-invasive tool for transplant monitoring, and initial findings support its potential role in rejection detection [79].

\section{Clinical Implications of T1 and T2 Mapping in Internal Medicine and Neurology}

$\mathrm{T} 1$ and T2 mapping are of important value for various diseases in internal medicine and neurology.

\section{Internal Medicine Diseases where the Value of T1 and T2 Mapping Is Currently Proven}

\section{Amyloidosis}

Amyloid deposition in the myocardium can be detected as patchy or subendocardial LGE with early blood pool darkening on Look Locker scout images. However, the amyloid deposition makes nulling of normal myocardium particularly difficult and may lead to difficulties in image interpretation [80]. Native T1 mapping overcomes the limitations of myocardial nulling, provides a quantitative assessment of diffuse extracellular expansion, and can also be applied in patients with renal failure, com- monly found in amyloidosis. It can also be used for serial evaluation of treatment [81].

\section{Autoimmune Rheumatic Diseases}

Cardiovascular disease is the main cause of increased mortality/morbidity in autoimmune rheumatic diseases, due to its silent presentation and the limitations of the currently used techniques that cannot perform tissue characterization [82]. Occult cardiovascular disease is common in rheumatoid arthritis, and up to $39 \%$ of rheumatoid arthritis patients have been reported to show focal LGE patterns, probably related to earlier myocarditis [83]. However, diffuse fibrosis is also common in rheumatoid arthritis and cannot be detected by LGE. In a pilot study, native $\mathrm{T} 1$ values were slightly elevated in rheumatoid arthritis patients compared with controls, and disease activity scores correlated positively with diffuse fibrosis regardless of LGE presence [84]. Furthermore, in ankylosing spondylitis myocardial ECV, quantified by $\mathrm{T} 1$ mapping was correlated with the degree of disease activity and may be a potential marker for disease monitoring [85].

Cardiac involvement is also common in systemic sclerosis and remains asymptomatic until the late stages of the disease. Low-grade inflammation, perfusion defects, and diffuse myocardial fibrosis have already been well described as co-existing factors [86]. They can be detected by T2-STIR and LGE imaging. However, LGE is limited in the assessment of diffuse myocardial fibrosis, especially when the entire myocardium is homogeneously affected [87].

The use of native T1 and T2 mapping has also facilitated the early detection of lupus myocarditis and mirrors the response to anti-inflammatory treatment [88]. Recently, Greulich et al. [89] documented that patients with ANCA-associated vasculitis demonstrated increased T1, $\mathrm{ECV}$, and T2 values, and these findings seem to be independent of LGE. Finally, myocardial tissue characterization using T1 and T2 mapping enabled the non-invasive detection of cardiac involvement and activity of myocardial inflammation in patients with systemic sarcoidosis [90]

\section{Iron Overload Disease}

The quantification of cardiac iron deposition in various iron overload diseases such as thalassemia, sickle cell disease, and myelodysplastic syndrome, is performed by T2*. This technique has been validated against pathology 
and represents the currently used gold standard for the non-invasive assessment of iron overload [91]. However, myocardial T1 mapping shows the potential for improved detection of mild iron loading, and its superior reproducibility has potential implications for clinical trial design and therapeutic monitoring [92]. Finally, ECV is significantly increased in thalassemia major and is associated with myocardial iron overload, as assessed by T2* [93].

\section{Evaluation of Cardiotoxicity Post-Chemotherapy}

Changes in contrast-enhanced T1-weighted signal intensity, upon which T1 mapping is based, occur with small but significant LVEF declines 3 months after the receipt of cardiotoxic chemotherapy and indicate that changes in T1-weighted signal intensity may serve as an early marker of subclinical injury related to cardiotoxic chemotherapy [94]. Additionally, myocardial T1 and ECV were found to be early tissue markers of ventricular remodelling in children with normal ejection fraction post-anthracycline therapy, and are related to cumulative dose, exercise capacity, and myocardial wall thinning [95].

\section{Neurologic Diseases where T1 and T2 Mapping Is Currently Proven Useful}

\section{Duchenne Muscular Dystrophy and Myotonic \\ Dystrophy}

Duchenne muscular dystrophy patients have elevated left ventricular myocardial native T1 and ECV, even if LVEF is normal and there is an absence of LGE, and therefore they have the potential to serve as surrogate cardiomyopathy indices to follow up outcome measures for clinical trials $[96,97]$. Similarly, myotonic dystrophy is also associated with structural alterations, and post-contrast myocardial T1 time was found to be shorter in these patients compared with controls, reflecting the presence of diffuse myocardial fibrosis [98].

\section{Limitations of T1 and T2 Mapping}

T1 and T2 mapping offer quantitative assessment of changes in tissue composition. However, one of the major obstacles for their clinical use is the variation in native T1 and T2 values related to imaging equipment and sequence. Further investigation is needed to establish "nor-

T1 and T2 Mapping in Heart Disease

mal" reference ranges for native $\mathrm{T} 1$ and $\mathrm{T} 2$ relaxation values because there is great variation among manufacturers, magnetic field strengths, and clinical parameters. These reference values are required to distinguish various disease conditions from normal myocardium, especially in cases of diffuse disease. Knowledge of the properties of specific MR scanners is necessary for the clinical application of these techniques.

Furthermore, the full clinical utility of T1 and T2 mapping is yet unknown because many diseases have not been adequately studied. There are still pending questions about (a) the potential replacement of LGE by native T1 mapping in the assessment of fibrosis, (b) whether native T1 mapping is more useful than T2 mapping in the evaluation of myocardial infarction, or whether they are complementary, and (c) how ECV can influence the clinical management of patients with heart disease.

\section{Conclusion}

Native and post-contrast T1 mapping, T2 mapping, and ECV provide important knowledge into fundamental disease processes affecting the myocardium that can otherwise be difficult to detect. Although it seems that they can significantly affect the clinical decision making, a multicentre application and a community-wide approach (including MRI vendors, funding agencies, academics, software companies, contrast agent manufacturers, and clinicians) are still missing. Therefore, more research is required before a large-scale application for clinical decision making can be recommended.

References

Cardiology 2017;138:207-217 DOI: $10.1159 / 000478901$
1 Kwon DH, Halley CM, Carrigan TP, Zysek V, Popovic ZB, Setser R, Schoenhagen P, Starling RC, Flamm SD, Desai MY: Extent of left ventricular scar predicts outcomes in ischemic cardiomyopathy patients with significantly reduced systolic function: a delayed hyperenhancement cardiac magnetic resonance study. JACC Cardiovasc Imaging 2009;2:3444.

2 Schelbert EB, Cao JJ, Sigurdsson S, Aspelund T, Kellman P, Aletras AH, Dyke CK, Thorgeirsson G, Eiriksdottir G, Launer LJ, Gudnason V, Harris TB, Arai AE: Prevalence and prognosis of unrecognized myocardial infarction determined by cardiac magnetic resonance in older adults. JAMA 2012;308:890896. 
3 Neilan TG, Coelho-Filho OR, Danik SB, Shah RV, Dodson JA, Verdini DJ, Tokuda M, Daly CA, Tedrow UB, Stevenson WG, JeroschHerold M, Ghoshhajra BB, Kwong RY: CMR quantification of myocardial scar provides additive prognostic information in nonischemic cardiomyopathy. JACC Cardiovasc Imaging 2013;6:944-954.

4 Gulati A, Jabbour A, Ismail TF, Guha K, Khwaja J, Raza S, Morarji K, Brown TD, Ismail NA, Dweck MR, Di Pietro E, Roughton M, Wage R, Daryani Y, O'Hanlon R, Sheppard MN, Alpendurada F, Lyon AR, Cook SA, Cowie MR, Assomull RG, Pennell DJ, Prasad SK: Association of fibrosis with mortality and sudden cardiac death in patients with nonischemic dilated cardiomyopathy. JAMA 2013;309:896-908.

5 Iles L, Pfluger H, Lefkovits L, Butler MJ, Kistler PM, Kaye DM, Taylor AJ: Myocardial fibrosis predicts appropriate device therapy in patients with implantable cardioverter-defibrillators for primary prevention of sudden cardiac death. J Am Coll Cardiol 2011;15: 821-828.

6 Mewton N, Liu CY, Croisille P, Bluemke D, Lima JA: Assessment of myocardial fibrosis with cardiovascular magnetic resonance. J Am Coll Cardiol 2011;57:891-903.

7 Nagel E, Narula J: Evolution and revolution in CMR imaging. JACC Cardiovasc Imaging 2013;6:837-838.

8 Moon JC, Messroghli DR, Kellman P, Piechnik SK, Robson MD, Ugander M, Gatehouse PD, Arai AE, Friedrich MG, Neubauer S, Schulz-Menger J, Schelbert EB: Myocardial T1 mapping and extracellular volume quantification: a Society for Cardiovascular Magnetic Resonance (SCMR) and CMR Working Group of the European Society of Cardiology consensus statement. J Cardiovasc Magn Reson 2013;15:92.

9 Ugander M, Bagi PS, Oki AJ, Chen B, Hsu LY, Aletras AH, Shah S, Greiser A, Kellman P, Arai AE: Myocardial edema as detected by pre-contrast T1 and T2 CMR delineates area at risk associated with acute myocardial infarction. JACC Cardiovasc Imaging 2012;5: 596-603.

10 Ferreira VM, Piechnik SK, Dall'Armellina E, Karamitsos TD, Francis JM, Choudhury RP, Friedrich MG, Robson MD, Neubauer S: Non-contrast T1-mapping detects acute myocardial edema with high diagnostic accuracy: a comparison to T2-weighted cardiovascular magnetic resonance. J Cardiovasc Magn Reson 2012;14:42.

11 Karamitsos TD, Piechnik SK, Banypersad SM, Fontana M, Ntusi NB, Ferreira VM, Whelan CJ, Myerson SG, Robson MD, Hawkins PN, Neubauer S, Moon JC: Noncontrast T1 mapping for the diagnosis of cardiac amyloidosis. JACC Cardiovasc Imaging 2013; 6:488-497.
12 Bull S, White SK, Piechnik SK, Flett AS, Ferreira VM, Loudon M, Francis JM, Karamitsos TD, Prendergast BD, Robson MD, Neubauer S, Moon JC, Myerson SG: Human non-contrast $\mathrm{T} 1$ values and correlation with histology in diffuse fibrosis. Heart 2013;99:932-937.

13 Sado DM, White SK, Piechnik SK, Banypersad SM, Treibel T, Captur G, Fontana M, Maestrini V, Flett AS, Robson MD, Lachmann RH, Murphy E, Mehta A, Hughes D, Neubauer S, Elliott PM, Moon JC: Identification and assessment of Anderson-Fabry disease by cardiovascular magnetic resonance noncontrast myocardial T1 mapping. Circ Cardiovasc Imaging 2013;6:392-398.

14 Scholz TD, Fleagle SR, Parrish FC, Breon T, Skorton DJ: Effect of tissue fat and water content on nuclear magnetic resonance relaxation times of cardiac and skeletal muscle. Magn Reson Imaging 1990;8:605-611.

15 Pedersen SF, Thrysoe SA, Robich MP, Paaske WP, Ringgaard S, Botker HE, Hansen ES, Kim WY: Assessment of intramyocardial hemorrhage by $\mathrm{T} 1$-weighted cardiovascular magnetic resonance in reperfused acute myocardial infarction. J Cardiovasc Magn Reson 2012;14:59.

16 Puntmann VO, D’Cruz D, Smith Z, Pastor A, Choong P, Voigt T, Carr-White G, Sangle S, Schaeffter T, Nagel E: Native myocardial T1 mapping by cardiovascular magnetic resonance imaging in subclinical cardiomyopathy in patients with systemic lupus erythematosus. Circ Cardiovasc Imaging 2013;6:295301.

17 Sado DM, White SK, Piechnik SK, Banypersad SM, Treibel T, Captur G, Fontana M, Maestrini V, Flett AS, Robson MD, Lachmann RH, Murphy E, Mehta A, Hughes D, Neubauer S, Elliott PM, Moon JC: The identification and assessment of Anderson-Fabry disease by cardiovascular magnetic resonance non-contrast myocardial T1 mapping. Circ Cardiovasc Imaging 2013;6:392-398.

18 Dall'Armellina E, Piechnik SK, Ferreira VM, Si QL, Robson MD, Francis JM, Cuculi F, Kharbanda RK, Banning AP, Choudhury RP, Karamitsos TD, Neubauer S: Cardiovascular magnetic resonance by noncontrast T1-mapping allows assessment of severity of injury in acute myocardial infarction. J Cardiovasc Magn Reson 2012;14:15.

19 Ferreira VM, Piechnik SK, Dall'armellina E, Karamitsos TD, Francis JM, Ntusi N, Holloway C, Choudhury RP, Kardos A, Robson MD, Friedrich MG, Neubauer S: T1 mapping for the diagnosis of acute myocarditis using CMR: comparison to T-weighted and late gadolinium enhanced imaging. JACC Cardiovasc Imaging 2013;6:1048-1058.

20 Messroghli DR, Walters K, Plein S, et al: Myocardial T1 mapping: application to patients with acute and chronic myocardial infarction. Magn Reson Med 2007;58:34-40.
21 Kim RJ, Chen EL, Lima JA, Judd RM: Myocardial Gd-DTPA kinetics determine MRI contrast enhancement and reflect the extent and severity of myocardial injury after acute reperfused infarction. Circulation 1996;94: 3318-3326.

22 Scholz TD, Fleagle SR, Burns TL, Skorton DJ: Nuclear magnetic resonance relaxometry of the normal heart: relationship between collagen content and relaxation times of the four chambers. Magn Reson Imaging 1989;7:643648.

23 Vogel-Claussen J, Rochitte CE, Wu KC, et al: Delayed enhancement MR imaging: utility in myocardial assessment. Radiographics 2006; 26:795-810.

24 Kellman P, Wilson JR, Xue H, Ugander M, Arai AE: Extracellular volume fraction mapping in the myocardium. Part 1. Evaluation of an automated method. J Cardiovasc Magn Reson 2012;14:63.

25 Weber KT, Brilla CG: Pathological hypertrophy and cardiac interstitium: fibrosis and renin-angiotensin-aldosterone system. Circulation 1991;83:1849-1865.

26 Wong TC, Piehler K, Meier CG, Testa SM, Klock AM, Aneizi AA, Shakesprere J, Kellman P, Shroff SG, Schwartzman DS, Mulukutla SR, Simon MA, Schelbert EB: Association between extracellular matrix expansion quantified by cardiovascular magnetic resonance and short-term mortality. Circulation 2012; 126:1206-1216.

27 Wong TC, Piehler K, Kang IA, Kadakkal A, Kellman P, Schwartzman DS, Mulukutla SR, Simon MA, Shroff SG, Kuller LH, Schelbert EB: Myocardial extracellular volume fraction quantified by cardiovascular magnetic resonance is increased in diabetes and associated with mortality and incident heart failure admission. Eur Heart J 2014;35:657-664.

28 Butler J, Fonarow GC, Gheorghiade M: Strategies and opportunities for drug development in heart failure. JAMA 2013;309:1593-1594.

29 Banypersad SM, Sado DM, Flett AS, Gibbs SDJ, Pinney JH, Maestrini V, Cox AT, Fontana M, Whelan CJ, Wechalekar AD, Hawkins PN, Moon JC: Quantification of myocardial extracellular volume fraction in systemic AL amyloidosis: an equilibrium contrast cardiovascular magnetic resonance study. Circ Cardiovasc Imaging 2012;6:34-39.

30 Fontana M, White SK, Banypersad SM, Sado DM, Maestrini V, Flett AS, Piechnik SK, Neubauer S, Roberts N, Moon JC: Comparison of T1 mapping techniques for ECV quantification: histological validation and reproducibility of ShMOLLI versus multibreath-hold T1 quantification equilibrium contrast CMR. J Cardiovasc Magn Reson 2012;14:88.

31 Brilla CG, Funck RC, Rupp H: Lisinopril-mediated regression of myocardial fibrosis in patients with hypertensive heart disease. Circulation 2000;102:1388-1393. 
32 Diez J, Querejeta R, Lopez B, Gonzalez A, Larman M, Martinez Ubago JL: Losartan-dependent regression of myocardial fibrosis is associated with reduction of left ventricular chamber stiffness in hypertensive patients. Circulation 2002;105:2512-2517.

33 Izawa H, Murohara T, Nagata K, Isobe S, Asano H, Amano T, Ichihara S, Kato T, Ohshima S, Murase Y, Iino S, Obata K, Noda A, Okumura K, Yokota M: Mineralocorticoid receptor antagonism ameliorates left ventricular diastolic dysfunction and myocardial fibrosis in mildly symptomatic patients with idiopathic dilated cardiomyopathy: a pilot study. Circulation 2005;112:2940-2945.

34 McLenachan JM, Dargie HJ: Ventricular arrhythmias in hypertensive left ventricular hypertrophy: relationship to coronary artery disease, left ventricular dysfunction, and myocardial fibrosis. Am J Hypertens 1990;3: 735-740.

35 Kawara T, Derksen R, de Groot JR, Coronel $\mathrm{R}$, Tasseron S, Linnenbank AC, Hauer RN, Kirkels H, Janse MJ, de Bakker JM: Activation delay after premature stimulation in chronically diseased human myocardium relates to the architecture of interstitial fibrosis. Circulation 2001;104:3069-3075.

36 Anderson KP, Walker R, Urie P, Ershler PR, Lux RL, Karwandee SV: Myocardial electrical propagation in patients with idiopathic dilated cardiomyopathy. J Clin Invest 1993;92: 122-140.

37 Tamarappoo BK, John BT, Reinier K, Teodorescu C, Uy-Evanado A, Gunson K, Jui J, Chugh SS: Vulnerable myocardial interstitium in patients with isolated left ventricular hypertrophy and sudden cardiac death: a postmortem histological evaluation. J Am Heart Assoc 2012;1:e001511.

38 Schwartzkopff B, Brehm M, Mundhenke M, Strauer BE: Repair of coronary arterioles after treatment with perindopril in hypertensive heart disease. Hypertension 2000;36:220225.

39 Naghavi M, Libby P, Falk E, Casscells SW, Litovsky S, Rumberger J, Badimon JJ, Stefanadis C, Moreno P, Pasterkamp G, Fayad Z, Stone PH, Waxman S, Raggi P, Madjid M, Zarrabi A, Burke A, Yuan C, Fitzgerald PJ, Siscovick DS, De Korte CL, Aikawa M, Juhani Airaksinen KE, Assmann G, Becker CR, Chesebro JH, Farb A, Galis ZS, Jackson C, Jang IK, et al: From vulnerable plaque to vulnerable patient: a call for new definitions and risk assessment strategies. Part I. Circulation 2003; 108:1664-1672.

40 Khavandi K, Khavandi A, Asghar O, Greenstein A, Withers S, Heagerty AM, Malik RA: Diabetic cardiomyopathy - a distinct disease? Best Pract Res Clin Endocrinol Metab 2009; 23:347-360.

41 Asbun J, Villarreal FJ: The pathogenesis of myocardial fibrosis in the setting of diabetic cardiomyopathy. J Am Coll Cardiol 2006;47: 693-700.
42 Goser S, Andrassy M, Buss SJ, Leuschner F, Volz CH, Ottl R, Zittrich S, Blaudeck N, Hardt SE, Pfitzer G, Rose NR, Katus HA, Kaya Z: Cardiac troponin I but not cardiac troponin $\mathrm{T}$ induces severe autoimmune inflammation in the myocardium. Circulation 2006;114:16931702.

43 Van Hoeven KH, Factor SM: A comparison of the pathological spectrum of hypertensive, diabetic, and hypertensive-diabetic heart disease. Circulation1990;82:848-855.

44 Beltrami CA, Finato N, Rocco M, Feruglio GA, Puricelli C, Cigola E, Quaini F, Sonnenblick EH, Olivetti G, Anversa P: Structural basis of end-stage failure in ischemic cardiomyopathy in humans. Circulation 1994;89:151163.

45 Beltrami CA, Finato N, Rocco M, Feruglio GA, Puricelli C, Cigola E, Sonnenblick EH, Olivetti G, Anversa P: The cellular basis of dilated cardiomyopathy in humans. J Mol Cell Cardiol 1995;27:291-305.

46 Schelbert EB, Cao JJ, Sigurdsson S, Aspelund T, Kellman P, Aletras AH, Dyke CK, Thorgeirsson G, Eiriksdottir G, Launer LJ, Gudnason V, Harris TB, Arai AE: Prevalence and prognosis of unrecognized myocardial infarction determined by cardiac magnetic resonance in older adults. JAMA 2012;308:890896.

47 Moon JC, Messroghli DR, Kellman P, Piechnik SK, Robson MD, Ugander M, Gatehouse PD, Arai AE, Friedrich MG, Neubauer S, Schulz-Menger J, Schelbert EB; Society for Cardiovascular Magnetic Resonance Imaging; Cardiovascular Magnetic Resonance Working Group of the European Society of Cardiology: Myocardial T1 mapping and extracellular volume quantification: a Society for Cardiovascular Magnetic Resonance (SCMR) and CMR Working Group of the European Society of Cardiology consensus statement. J Cardiovasc Magn Reson 2013;15:92.

48 Wong TC, Piehler K, Puntil KS, Moguillansky D, Meier CG, Lacomis JL, Kellman P, Cook SC, Schwartzman DS, Simon MA, Mulukutla SR, Schelbert EB: Effectiveness of late gadolinium enhancement to improve outcomes prediction in patients referred for cardiovascular magnetic resonance after echocardiography. J Cardiovasc Magn Reson 2013;15:1.

49 Cheong BY, Muthupillai R, Wilson JM, Sung A, Huber S, Amin S, Elayda MA, Lee VV, Flamm SD: Prognostic significance of delayed-enhancement magnetic resonance imaging: survival of 857 patients with and without left ventricular dysfunction. Circulation 2009;120:2069-2076.

50 Klem I, Shah DJ, White RD, Pennell DJ, Van Rossum AC, Regenfus M, Sechtem U, Schvartzman PR, Hunold P, Croisille P, Parker M, Judd RM, Kim RJ: Prognostic value of routine cardiac magnetic resonance assessment of left ventricular ejection fraction and myocardial damage: an international multicenter study. Circ Cardiovasc Imaging 2011;4:610-619.
51 Kim RJ, Wu E, Rafael A, Chen EL, Parker MA, Simonetti O, Klocke FJ, Bonow RO, Judd RM: The use of contrast-enhanced magnetic resonance imaging to identify reversible myocardial dysfunction. N Engl J Med 2000;343: 1445-1453.

52 Gulati A, Jabbour A, Ismail TF, Guha K, Khwaja J, Raza S, Morarji K, Brown TD, Ismail NA, Dweck MR, Di Pietro E, Roughton M, Wage R, Daryani Y, O'Hanlon R, Sheppard MN, Alpendurada F, Lyon AR, Cook SA, Cowie MR, Assomull RG, Pennell DJ, Prasad SK: Association of fibrosis with mortality and sudden cardiac death in patients with nonischemic dilated cardiomyopathy. JAMA 2013;309:896-908.

53 De Waha S, Desch S, Eitel I, Fuernau G, Zachrau J, Leuschner A, Gutberlet M, Schuler G, Thiele H: Impact of early vs. late microvascular obstruction assessed by magnetic resonance imaging on long-term outcome after ST-elevation myocardial infarction: a comparison with traditional prognostic markers. Eur Heart J 2010;31:2660-2668.

54 Sado DM, Flett AS, Banypersad SM, White SK, Maestrini V, Quarta G, Lachmann RH, Murphy E, Mehta A, Hughes DA, McKenna WJ, Taylor AM, Hausenloy DJ, Hawkins PN, Elliott PM, Moon JC: Cardiovascular magnetic resonance measurement of myocardial extracellular volume in health and disease. Heart 2012;98:1436-1441.

55 Kidambi A, Motwani M, Uddin A, Ripley DP, McDiarmid AK, Swoboda PP, Broadbent DA, Musa TA, Erhayiem B, Leader J, Croisille P, Clarysse P, Greenwood JP, Plein S: Myocardial extracellular volume estimation by CMR predicts functional recovery following acute MI. JACC Cardiovasc Imaging 2016, Epub ahead of print.

56 Broberg CS, Chugh SS, Conklin C, Sahn DJ, Jerosch-Herold M: Quantification of diffuse myocardial fibrosis and its association with myocardial dysfunction in congenital heart disease. Circ Cardiovasc Imaging 2010;3:727734.

57 Ugander M, Oki AJ, Hsu LY, Kellman P, Greiser A, Aletras AH, Sibley CT, Chen MY, Bandettini WP, Arai AE: Extracellular volume imaging by magnetic resonance imaging provides insights into overt and sub-clinical myocardial pathology. Eur Heart J 2012;33: 1268-1278.

58 Flett AS, Sado DM, Quarta G, Mirabel M, Pellerin D, Herrey AS, Hausenloy DJ, Ariti C, Yap J, Kolvekar S, Taylor AM, Moon JC: Diffuse myocardial fibrosis in severe aortic stenosis: an equilibrium contrast cardiovascular magnetic resonance study. Eur Heart J Cardiovasc Imaging 2012;13:819-826.

59 Mongeon FP, Jerosch-Herold M, Coelho-Filho OR, Blankstein R, Falk RH, Kwong RY: Quantification of extracellular matrix expansion by CMR in infiltrative heart disease. JACC Cardiovasc Imaging 2012;5:897-907. 
60 Flett AS, Hayward MP, Ashworth MT, Hansen MS, Taylor AM, Elliott PM, McGregor C Moon JC: Equilibrium contrast cardiovascular magnetic resonance for the measurement of diffuse myocardial fibrosis: preliminary validation in humans. Circulation 2010;122: 138-144.

61 Coelho-Filho OR, Shah RV, Mitchell R, Neilan TG, Moreno H Jr, Simonson B, Kwong R, Rosenzweig A, Das S, Jerosch-Herold M: Quantification of cardiomyocyte hypertrophy by cardiac magnetic resonance: implications for early cardiac remodeling. Circulation 2013;128:1225-1233.

62 Coelho-Filho OR, Shah RV, Neilan TG, Mitchell R, Moreno H Jr, Kwong R, JeroschHerold M: Cardiac magnetic resonance assessment of interstitial myocardial fibrosis and cardiomyocyte hypertrophy in hypertensive mice treated with spironolactone. J Am Heart Assoc 2014;3:e000790.

63 Iles L, Pfluger H, Phrommintikul A, Cherayath J, Aksit P, Gupta SN, Kaye DM, Taylor AJ: Evaluation of diffuse myocardial fibrosis in heart failure with cardiac magnetic resonance contrast-enhanced T1 mapping. J Am Coll Cardiol 2008;52:1574-1580.

64 Sibley CT, Noureldin RA, Gai N, Nacif MS, Liu S, Turkbey EB, Mudd JO, van der Geest RJ, Lima JA, Halushka MK, Bluemke DA: T1 mapping in cardiomyopathy at cardiac MR: comparison with endomyocardial biopsy. Radiology 2012;265:724-732.

65 Heling A, Zimmermann R, Kostin S, Maeno Y, Hein S, Devaux B, Bauer E, Klövekorn WP, Schlepper M, Schaper W, Schaper J: Increased expression of cytoskeletal, linkage, and extracellular proteins in failing human myocardium. Circ Res 2000;86:846-853.

66 Beltrami CA, Finato N, Rocco M, Feruglio GA, Puricelli C, Cigola E, Sonnenblick EH, Olivetti G, Anversa P: The cellular basis of dilated cardiomyopathy in humans. J Mol Cell Cardiol 1995;27:291-305.

67 Ellims AH, Iles LM, Ling LH, Hare JL, Kaye DM, Taylor AJ: Diffuse myocardial fibrosis in hypertrophic cardiomyopathy can be identified by cardiovascular magnetic resonance, and is associated with left ventricular diastolic dysfunction. J Cardiovasc Magn Reson 2012;14:76

68 Ho CY, Abbasi SA, Neilan TG, Shah RV, Chen Y, Heydari B, Cirino AL, Lakdawala NK, Orav EJ, González A, López B, Díez J, Jerosch-Herold M, Kwong RY: T1 measurements identify extracellular volume expansion in hypertrophic cardiomyopathy sarcomere mutation carriers with and without left ventricular hypertrophy. Circ Cardiovasc Imaging 2013;6:415-422.

69 Moon JC, Reed E, Sheppard MN, Elkington AG, Ho SY, Burke M, Petrou M, Pennell DJ: The histologic basis of late gadolinium enhancement cardiovascular magnetic resonance in hypertrophic cardiomyopathy. J Am Coll Cardiol 2004;43:2260-2264.
70 Ellims AH, Iles LM, Ling LH, Chong B, Macciocca I, Slavin GS, Hare JL, Kaye DM, Marasco SF, McLean CA, James PA, du Sart D, Taylor AJ: A comprehensive evaluation of myocardial fibrosis in hypertrophic cardiomyopathy with cardiac magnetic resonance imaging: linking genotype with fibrotic phenotype. Eur Heart J Cardiovasc Imaging 2014; 15:1108-1116.

71 Verhaert D, Thavendiranathan P, Giri S, Mihai G, Rajagopalan S, Simonetti OP, et al: Direct $\mathrm{T} 2$ quantification of myocardial edema in acute ischemic injury. JACC Cardiovasc Imaging 2011;4:269-278.

72 Thavendiranathan P, Walls M, Giri S, Verhaert D, Rajagopalan S, Moore S, et al: Improved detection of myocardial involvement in acute inflammatory cardiomyopathies using T2 mapping. Circ Cardiovasc Imaging 2012;5:102-110.

73 Roller FC, Harth S, Schneider C, Krombach GA: T1, T2 mapping and extracellular volume fraction (ECV): application, value and further perspectives in myocardial inflammation and cardiomyopathies. Rofo 2015;187:760-770.

74 Crouser ED, Ono C, Tran T, He X, Raman SV: Improved detection of cardiac sarcoidosis using magnetic resonance with myocardial T2 mapping. Am J Respir Crit Care Med 2014; 189:109-112.

75 Usman AA, Taimen K, Wasielewski M, McDonald J, Shah S, Giri S, et al: Cardiac magnetic resonance $\mathrm{T} 2$ mapping in the monitoring and follow-up of acute cardiac transplant rejection: a pilot study. Circ Cardiovasc Imaging 2012;5:782-790.

76 Giri S, Shah S, Xue H, Chung YC, Pennell ML, Guehring J, et al: Myocardial T2 mapping with respiratory navigator and automatic nonrigid motion correction. Magn Reson Med 2012;68:1570-1578.

77 von Knobelsdorff-Brenkenhoff F, Prothmann M, Dieringer MA, Wassmuth R, Greiser A, Schwenke C, et al: Myocardial T1 and T2 mapping at $3 \mathrm{~T}$ : reference values, influencing factors and implications. J Cardiovasc Magn Reson 2013;15:53.

78 Bohnen S, Radunski UK, Lund GK, Kandolf R, Stehning C, Schnackenburg B, Adam G, Blankenberg S, Muellerleile K: Performance of $\mathrm{t} 1$ and $\mathrm{t} 2$ mapping cardiovascular magnetic resonance to detect active myocarditis in patients with recent-onset heart failure. Circ Cardiovasc Imaging 2015;8:e003073

79 Usman AA, Taimen K, Wasielewski M, McDonald J, Shah S, Giri S, Cotts W, McGee E, Gordon R, Collins JD, Markl M, Carr JC: Cardiac magnetic resonance T2 mapping in the monitoring and follow-up of acute cardiac transplant rejection: a pilot study. Circ Cardiovasc Imaging 2012;5:782-790.

80 Maceira AM, Joshi J, Prasad SK, Moon JC, Perugini E, Harding I, Sheppard MN, PooleWilson PA, Hawkins PN, Pennell DJ: Cardiovascular magnetic resonance in cardiac amyloidosis. Circulation 2005;111:186-193.
81 Ruberg FL: T1 mapping in cardiac amyloidosis: can we get from here? JACC Cardiovasc Imaging 2013;6:498-500.

82 Mavrogeni SI, Kitas GD, Dimitroulas T, Sfikakis PP, Seo P, Gabriel S, Patel AR, Gargani L, Bombardieri S, Matucci-Cerinic M, Lombardi M, Pepe A, Aletras AH, Kolovou G, Miszalski T, van Riel P, Semb A, GonzalezGay MA, Dessein P, Karpouzas G, Puntmann V, Nagel E, Bratis K, Karabela G, Stavropoulos E, Katsifis G, Koutsogeorgopoulou L, van Rossum A, Rademakers F, Pohost G, Lima JA: Cardiovascular magnetic resonance in rheumatology: current status and recommendations for use. Int J Cardiol 2016;217:135-148.

83 Kobayashi Y, Giles JT, Hirano M, Yokoe I, Nakajima Y, Bathon JM, Lima JA, Kobayashi $\mathrm{H}$ : Assessment of myocardial abnormalities in rheumatoid arthritis using a comprehensive cardiac magnetic resonance approach: a pilot study. Arthritis Res Ther 2010;12:R171.

84 Ntusi NA, Piechnik SK, Francis JM, Ferreira VM, Matthews PM, Robson MD, Wordsworth PB, Neubauer S, Karamitsos TD: Diffuse myocardial fibrosis and inflammation in rheumatoid arthritis: insights from CMR T1 mapping. JACC Cardiovasc Imaging 2015;8: 526-536.

85 Biesbroek PS, Heslinga SC, Konings TC, van der Horst-Bruinsma IE, Hofman MBM, van de Ven PM, Kamp O, van Halm VP, Peters MJL, Smulders YM, van Rossum AC, Nurmohamed MT, Nijveldt R: Insights into cardiac involvement in ankylosing spondylitis from cardiovascular magnetic resonance. Heart 2017;103:745-752.

86 Mavrogeni SI, Bratis K, Karabela G, Spiliotis G, van Wijk K, Hautemann D, Reiber JH, Koutsogeorgopoulou L, Markousis-Mavrogenis G, Kolovou G, Stavropoulos E: Cardiovascular magnetic resonance imaging clarifies cardiac pathophysiology in early, asymptomatic diffuse systemic sclerosis. Inflamm Allergy Drug Targets 2015;14:29-36.

87 Ntusi NA, Piechnik SK, Francis JM, Ferreira VM, Matthews PM, Robson MD, Wordsworth PB, Neubauer S, Karamitsos TD: Subclinical myocardial inflammation and diffuse fibrosis are common in systemic sclerosis - a clinical study using myocardial T1-mapping and extracellular volume quantification. J Cardiovasc Magn Reson 2014;16:21.

88 Hinojar R, Foote L, Sangle S, Marber M, Mayr M, Carr-White G, D'Cruz D, Nagel E, Puntmann VO: Native T1 and T2 mapping by CMR in lupus myocarditis: disease recognition and response to treatment. Int J Cardiol 2016;222:717-726.

89 Greulich S, Mayr A, Kitterer D, Latus J, Henes J, Steubing H, Kaesemann P, Patrascu A, Greiser A, Groeninger S, Braun N, Alscher MD, Sechtem U, Mahrholdt H: T1 and T2 mapping for evaluation of myocardial involvement in patients with ANCA-associated vasculitides. J Cardiovasc Magn Reson 2017; 19:6. 
90 Puntmann VO, Isted A, Hinojar R, Foote L, Carr-White G, Nagel E: T1 and T2 mapping in recognition of early cardiac involvement in systemic sarcoidosis. Radiology 2017;2017: 162732.

91 Pennell DJ, Udelson JE, Arai AE, Bozkurt B, Cohen AR, Galanello R, Hoffman TM, Kiernan MS, Lerakis S, Piga A, Porter JB, Walker JM, Wood J; American Heart Association Committee on Heart Failure and Transplantation of the Council on Clinical Cardiology and Council on Cardiovascular Radiology and Imaging: Cardiovascular function and treatment in $\beta$-thalassemia major: a consensus statement from the American Heart Association. Circulation 2013;128:281-308.

92 Sado DM, Maestrini V, Piechnik SK, Banypersad SM, White SK, Flett AS, Robson MD, Neubauer S, Ariti C, Arai A, Kellman P, Yamamura J, Schoennagel BP, Shah F, Davis B, Trompeter S, Walker M, Porter J, Moon JC: Noncontrast myocardial T1 mapping using cardiovascular magnetic resonance for iron overload. J Magn Reson Imaging 2015;41: 1505-1511.

93 Hanneman K, Nguyen ET, Thavendiranathan P, Ward R, Greiser A, Jolly MP, Butany J, Yang IY, Sussman MS, Wintersperger BJ: Quantification of myocardial extracellular volume fraction with cardiac MR imaging in thalassemia major. Radiology 2016;279:720730.

94 Jordan JH, D'Agostino RB Jr, Hamilton CA, Vasu S, Hall ME, Kitzman DW, Thohan V, Lawrence JA, Ellis LR, Lash TL, Hundley WG: Longitudinal assessment of concurrent changes in left ventricular ejection fraction and left ventricular myocardial tissue characteristics after administration of cardiotoxic chemotherapies using T1-weighted and T2weighted cardiovascular magnetic resonance. Circ Cardiovasc Imaging 2014;7:872-879.

95 Tham EB, Haykowsky MJ, Chow K, Spavor M, Kaneko S, Khoo NS, Pagano JJ, Mackie AS, Thompson RB: Diffuse myocardial fibrosis by T1-mapping in children with subclinical an- thracycline cardiotoxicity: relationship to exercise capacity, cumulative dose and remodelling. J Cardiovasc Magn Reson 2013;15:48.

96 Soslow JH, Damon SM, Crum K, Lawson MA, Slaughter JC, Xu M, Arai AE, Sawyer DB, Parra DA, Damon BM, Markham LW: Increased myocardial native T1 and extracellular volume in patients with Duchenne muscular dystrophy. J Cardiovasc Magn Reson 2016;18:5.

97 Florian A, Ludwig A, Rösch S, Yildiz H, Sechtem U, Yilmaz A: Myocardial fibrosis imaging based on T1-mapping and extracellular volume fraction (ECV) measurement in muscular dystrophy patients: diagnostic value compared with conventional late gadolinium enhancement (LGE) imaging. Eur Heart J Cardiovasc Imaging 2014;15:1004-1012.

98 Turkbey EB, Gai N, Lima JA, van der Geest RJ, Wagner KR, Tomaselli GF, Bluemke DA, Nazarian S: Assessment of cardiac involvement in myotonic muscular dystrophy by $\mathrm{T} 1$ mapping on magnetic resonance imaging. Heart Rhythm 2012;9:1691-1697. 